\title{
Calentamiento por láser: una técnica mínimamente invasiva para el estudio del calentamiento producido por el fuego en materiales pétreos de construcción
}

\section{Laser heating: a minimally invasive technique for studying fire-generated heating in building stone}

\author{
$\underline{\text { M. Gomez-Heras }}^{(*)}$, R. Fort( ${ }^{(* *)}$, M. Morcillo(***), C. Molpeceres ${ }^{(* * *)}$ y J. L. Ocaña(***)
}

Recepción/Received: 20-VI-07

Aceptación/Accepted: 11-XI-07

Publicado online/Online publishing: 15-I-08

\section{RESUMEN}

El fuego es una de las amenazas más importantes para los edificios debido a la escala de pérdidas irreparables que genera. Los estudios sobre los efectos del fuego se han dirigido recientemente hacia escalas de observación más detalladas, que son más adecuadas para el estudio de muestras de edificios patrimoniales, como microfisuración y cambios mineralógicos y químicos. Las técnicas de simulación de fuegos empleadas hasta ahora (ensayos con hornos y llamas reales) presentan varias limitaciones como, por ejemplo, la falta de repetibilidad, ausencia de sub-productos de combustión o, especialmente, el uso de muestras de gran tamaño. Por esta última razón, es importante encontrar técnicas en las que se pueda usar cantidades mínimas de muestra. Este artículo presenta la irradiación láser como una técnica adecuada para simular el "quemado" de materiales de construcción, ya que ofrece una física de calentamiento similar al fuego, repetibilidad de los experimentos $y$, sobre todo, utiliza menos cantidad de muestra. La irradiación láser permite concentrar una alta energía en un área pequeña, con lo que se pueden realizar ensayos a microescala en muestras pequeñas tomadas de edificios.

Palabras clave: deterioro de la piedra, fuego, irradiación láser, técnicas no invasivas, arenisca.

\section{SUMMARY}

Fire is one of the most significant threats to buildings due to the scale of irreparable loss that it generates. Studies on fire effects have shifted recently to more detailed scales of observation, such as micro-cracking, mineralogical and chemical changes, which are more adequately applied to samples from listed buildings. Fire simulation techniques hitherto employed (furnace techniques and real flame tests) may present several limitations such as, for example, the lack of repeatability, the lack of combustion sub-products or, especially, the requirement of large samples. For this last reason it is important to find techniques in which minimal amounts of sample can be used. This paper presents laser irradiation as a suitable technique to simulate "burning" of building materials, as it offers heating physics similar to fire, repeatability of the experiments, the possibility of including the combustion products and, most importantly, it uses less sample material. Laser irradiation allows concentrating a high energy in a small area, permitting tests at micro-scales on small samples collected from buildings.

Keywords: stone decay, fire, laser irradiation, non-invasive techniques, sandstone.

(*) (Queen's University) (Belfast, UK).

(**) Instituto de Geología Económica, CSIC-UCM (Madrid, España).

(***) Centro Tecnológico Láser, Universidad Politécnica de Madrid (Madrid, España). 


\section{INTRODUCCIÓN}

El fuego es uno de los agentes de deterioro que puede generar rápidamente un deterioro catastrófico en cualquier edificio. Prácticamente todos los materiales de construcción son sensibles al fuego en mayor o menor medida. Incluso materiales como la piedra, considerados en muchos casos como resistentes al fuego, sufren importantes modificaciones, tanto como resultado directo del fuego o, indirectamente, a largo plazo. La importancia del fuego como agente de deterioro aumenta en el caso de edificios históricos o de valor singular, en los que la pérdida de un bien cultural se añade a los daños materiales.

Estimaciones en el marco de la reciente acción COST C17 (Built Heritage: Fire Loss to Historic Buildings) han mostrado que en la UE se pierde una media de un edificio al día a consecuencia del fuego. Casos recientes con gran repercusión en la prensa como el incendio de la Catedral de la Santa Trinidad en San Petersburgo (25/08/06), o del Cutty Sark en Londres (21/05/07) son sólo un pequeño ejemplo del grave problema que supone el fuego para el patrimonio. De tal forma, la evaluación de los procesos a través de los que el fuego deteriora materiales y estructuras se mantiene como una de las prioridades principales para entender este agente y planear estrategias para la protección de los edificios patrimoniales.

La piedra es el principal constituyente de gran parte del patrimonio cultural tangible del mundo y, por tanto, es muy importante el estudio del deterioro de la piedra natural a causa del fuego. Desgraciadamente, aunque los estudios en el laboratorio han buscado evaluar el deterioro que el fuego genera en la piedra, esta investigación, especialmente en edificios patrimoniales, se ve limitada por la falta de normalización específica y la gran cantidad de muestra necesaria para realizar estudios de laboratorio.

La mayoría de los estudios realizados hasta la fecha sobre los efectos del fuego en piedra natural se han llevado a cabo con hornos de laboratorio convencionales, sometiendo cilindros o cubos de tamaño considerable $(4 \mathrm{~cm}$ o mayores) a una rampa controlada de ascenso de temperatura (1-7). Tras esto, las muestras se sometían a un proceso de choque térmico mediante inmersión en agua (3) o un descenso gradual de temperatura $(1,4)$. En ambos casos las condiciones de los experimentos no reflejan enteramente los procesos que tienen lugar durante un fuego natural (6).

Otras investigaciones más recientes han optado por el uso de pequeños fuegos controlados (8-10). Sin embargo, estas técnicas aún no se han desarrollado completamente en lo que se refiere a su metodología y al control de las condiciones experimentales.

\section{INTRODUCTION}

No building is completely immune to the catastrophic damage that fire can potentially cause. Nearly all construction materials are subject to fire damage to some extent. Even materials often regarded to be fire-resistant, such as stone, may be substantially impacted by fire, either immediately, as a direct consequence of fire, or indirectly in the long term. The importance of fire damage is even greater in historic buildings or structures of exceptional value, where material loss is compounded by the loss of cultural heritage.

According to estimates made in the framework of the recent COST C17 action (Built Heritage: Fire Loss to Historic Buildings), on average more than one listed building is lost to fire every day in the EU. The widely publicized recent fires in heritage structures such as Holy Trinity Cathedral (Saint Petersburg, 25/08/06) or the Cutty Sark (London, 21/05/07) are mere tokens of the severity of fire risk to heritage. The assessment of the processes involved in fire damage to materials and structures is, then, one of the first priorities for understanding this hazard and planning strategies to protect heritage buildings.

Inasmuch as stone is the main constituent of much of the world's tangible heritage, the study of fire damage to this material is of cardinal importance. While laboratory analyses have sought to assess the physical damage to building stone caused by fire, research in this regard and in particular in the context of heritage structures is hampered by the lack of standardized test methods and the large amount of sample needed for laboratory trials.

To date, most studies on fire damage to building stone have been conducted by heating fairly large cubes or cylinders (over $4 \mathrm{~cm}$ ) (1-7) in conventional laboratory furnaces, ramping up the temperature to a preset schedule. This treatment is followed either by thermal shock in the form of immersion in water (3) or gradual cooling $(1,4)$. In neither case do the test conditions fully reflect the processes that take place in real fires (6).

More recently, research has been geared to the use of small scale controlled fires (8-10). The methods involved and control of the experimental conditions have yet to be fully developed, however. 
Durante un fuego hay principalmente dos agentes que pueden modificar los materiales; el primero es el calor. El calentamiento durante un incendio se produce principalmente por radiación (11). Los procesos químicos que involucran al combustible y a los productos gaseosos (por ejemplo, cambios en los estados de excitación o disociación de compuestos) liberan energía en forma de radiación calorífica que se sitúa en las zonas visible e infrarroja del espectro electromagnético. Esto genera una emisión tipo cuerpo gris (13) con intensidades que llegan hasta los $100 \mathrm{KW} / \mathrm{m}^{2}$ (11), debido principalmente a la presencia de partículas en las zonas más calientes y de mayor luminosidad de las llamas, siendo secundaria la contribución de los componentes gaseosos (12).

El segundo agente incluye las cenizas y componentes sólidos en las emisiones gaseosas que resultan del fuego. Las cenizas ennegrecen la piedra al introducirse en el sistema poroso (12) y pueden deteriorar a largo plazo, debido a la cristalización de sales formadas a partir de la reacción con lixiviados de las cenizas $(14,15)$.

Los ensayos de laboratorio que utilizan hornos no reflejan la misma dinámica de calentamiento de un fuego, ya que en ellos el calentamiento es por convección y, por tanto, la respuesta térmica de la piedra es muy diferente (15-17). Estos ensayos tampoco consideran los efectos de los componentes sólidos que forman parte de las emisiones de un fuego.

A la inversa, los ensayos realizados con fuegos controlados tienen en cuenta la presencia de residuos de combustión y permiten establecer su influencia a largo plazo en combinaciones complejas de agentes de deterioro (810). Sin embargo, estos ensayos también tienen importantes limitaciones que incluyen la falta de control sobre las condiciones de quemado y el uso de muestras de gran tamaño, como en el caso de los experimentos en hornos.

Más aún, el gran tamaño de muestras necesarias para los ensayos tanto en hornos como en fuegos controlados no es compatible con el tipo de muestras que se pueden obtener directamente de edificios históricos y, por tanto, requieren la utilización de muestras de cantera.

Aunque el uso de muestras de cantera como estándar para la cuantificación del deterioro es una práctica común, no siempre se pueden obtener muestras de las canteras originales de edificios patrimoniales. Además, las muestras de cantera no tienen en cuenta la historia de agentes de deterioro que el material ha experimentado en desde su colocación en el edificio. El carácter puntual del fuego realza la importancia de ensayar los materiales teniendo en cuenta esta historia de deterioro previa al incendio, puesto que ésta va a condicionar el efecto del fuego sobre la piedra $(15,18)$. De tal forma, es importan-
The first of the two chief agents that may impact stone during fires is heat. The main heating mechanism during fire, in turn, is radiation (11). The chemical processes involving the emission of fuel and gas (such as changes in excitation status or dissociation of compounds) release energy in the form of heat radiation in the visible and infrared parts of the electromagnetic spectrum. This generates grey body type emissions (13) with intensities of up to $100 \mathrm{~kW} / \mathrm{m}^{2}(11)$, due primarily to the presence of particles in the hottest and brightest areas of the flames and secondarily to the gas components (12).

The ashes and the solid fraction in the fumes comprise the second of the two agents. Ashes blacken stone as they penetrate the pores (12) and the salts crystallizing from the products leached out of the ashes may cause decay in the long term $(14,15)$.

Laboratory tests using convection furnaces do not generate the same heating conditions as fire and therefore elicit a very different response from the stone (15-17). Nor are such methods able to take account of the effects of the solids held within real fumes.

Controlled fire testing, on the contrary, takes such combustion residue into consideration, assessing its longterm impact in complex combinations of decay factors (810). Nonetheless, these tests also require large samples and are subject to other significant drawbacks such as the limited control afforded over burning conditions.

Moreover, since the large sample size needed for both furnace and controlled fire tests is incompatible with the kind of samples obtained directly from historic buildings, fresh quarry samples are generally used instead.

Although the use of quarry samples as a baseline for the assessment of stone decay is standard practice, it is not always possible to obtain samples from the original quarry that supplied the stone for a specific historic building. Furthermore, quarry samples do not account for the history of decay of stone laid in buildings. The fact that fire is generally a one-time event heightens the need to be able to test materials in ways that take account of prior decay, for the impact of fire on stone is highly dependent on that history $(15,18)$. Stone with a similar background of decay should therefore be used in labora- 
te para la experimentación en el laboratorio utilizar material con una historia de deterioro similar. Esto sólo se puede conseguir utilizando muestras de los propios edificios y, para esto, la técnica de ensayo debe ser compatible con el uso de cantidades de muestra muy pequeñas para minimizar los daños a los edificios históricos.

Este artículo presenta la técnica láser como una alternativa a los ensayos tradicionales de quemado/calentamiento de materiales de construcción ya que ofrece resultados realistas en muestras de pequeño tamaño provenientes de edificios históricos. Para ello, se experimentó con una arenisca utilizada en edificios patrimoniales, validando los resultados de la simulación en laboratorio con resultados observados en fuegos reales.

\section{MATERIALES Y MÉTODOS}

Para este estudio se trabajó con un láser continuo de diodo Rofin-Sinar DL 27 (Figura 1), guiado por fibra óptica hacia un cabezal libre, con una potencia máxima de $2700 \mathrm{~W}$ nominales (con unas pérdidas tabuladas de un $15 \%$ ). Un láser de diodo es aquél en el cual el medio activo es un semiconductor ópticamente activo, similar al que se encuentra en un diodo tipo LED. Este láser tiene dos conjuntos de diodos que emiten en dos longitudes de onda diferentes en el infrarrojo cercano (808 y $940 \mathrm{~nm}$ ) incluidas en la zona térmica del espectro de un fuego normal. El enfoque se obtiene mediante un triplete con distancia focal de $60 \mathrm{~mm}$ para una huella o spot de $2 \mathrm{~mm}$ de diámetro. El spot es circular, siendo la intensidad de la radiación $\left(\mathrm{W} / \mathrm{m}^{2}\right)$ prácticamente constante en el interior del spot, lo que permite una acción uniforme de la radiación en el area de ensayo. tory experiments. Where this can only be obtained by taking samples from the building itself, the test methods used must be viable with only small samples to minimize damage to historic buildings.

This paper discusses laser irradiation as an alternative to traditional building stone burning/heating test methods, as it yields realistic results with small samples. The viability of laser irradiation was assessed by testing samples of sandstone found in historic buildings and comparing the results to the findings for material burnt in real fires.

\section{MATERIALS AND METHODS}

A 2700W Rofin-Sinar DL 27 continuous diode laser (Figure 1) guided by an optic fibre to a free head (with a tabulated $15 \%$ loss of nominal output power) was used for these tests. In diode lasers, the active medium is an optically active semiconductor, similar to the ones found in light emission diodes (LEDs). This laser has two sets of diodes emitting at two near infrared wavelengths (808 and $940 \mathrm{~nm}$ ) within the thermal portion of a standard fire spectrum. The beam is adjusted with a triplet lens whose focal length for a 2-mm spot diameter is $60 \mathrm{~mm}$. Radiation intensity $\left(\mathrm{W} / \mathrm{m}^{2}\right)$ is constant within this circular spot, ensuring uniform radiation in the test area.

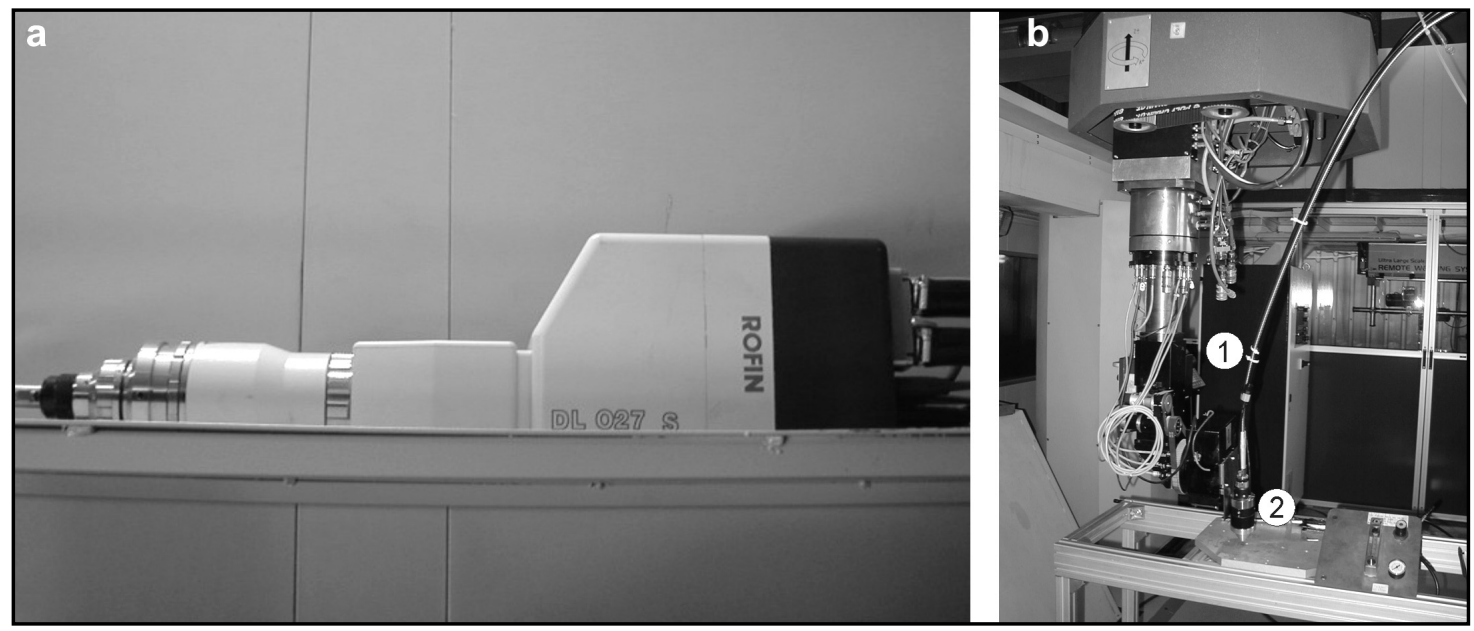

Figura 1. Láser de diodo utilizado en estos experimentos (a). El haz láser se conduce por medio de una fibra óptica (1) hasta el cabezal (2) en la zona de ensayo (b).

Figure 1. Diode laser employed in these experiments (a). The laser beam is conducted through a fiber optic cable (1) to the head (2) in the testing area (b). 
Los principales parámetros que se controlaron al diseñar el experimento son:

Distancia entre el foco del láser y la muestra. Determina el tamaño del spot. Como el rayo emitido es cónico, cuanto más lejos está la muestra del cabezal del láser, más grande es el spot. Variando la distancia al foco podemos controlar el área de aplicación más adecuada para los ensayos.

Potencia del láser. Esto condiciona la intensidad de la radiación incidente y, por tanto, la energía del fuego que se intenta simular.

Tiempo de exposición a la radiación. Esto tiene como objetivo valorar si la acción prolongada de una radiación de menor intensidad produce efectos similares que una radiación mayor durante menos tiempo. Los tiempos se midieron desde el punto de estabilización de la temperatura.

Se realizaron una serie de ensayos previos para establecer los parámetros más adecuados del láser para que los experimentos reflejasen las condiciones experimentadas en un fuego en un edificio. Así, se realizaron una serie de ensayos con potencias nominales de 300 a $400 \mathrm{~W}$ (aproximadamente 30 a $45 \mathrm{~kW} / \mathrm{m}^{2}$ efectivos para un spot de $7,5 \mathrm{~mm}$ de diametro) y se compararon los resultados con las observaciones realizadas en el mismo material quemado en un incendio real (Figura 2). Estos valores de potencia se seleccionaron en un intento de obtener valores más representativos que la intensidad máxima para un incendio citada anteriormente $\left(100 \mathrm{~kW} / \mathrm{m}^{2}(11)\right)$. El
The main parameters controlled in the experimental design were:

Focal distance. This is the distance between the laser head and the sample, which determines the spot size. Since the laser beam is conical, the farther the sample is from the laser head, the larger is the spot. The area beamed can therefore be adjusted by varying the distance between the sample and the laser head.

Laser power. This variable controls the intensity of the incident radiation and consequently of the fire to be simulated.

Exposure time. This parameter was varied to explore the possible similarity between prolonged exposure to low intensity, and short exposure to high intensity radiation. Time was measured once surface temperature estabilized.

The laser parameters that would reflect the conditions prevailing in a building fire as accurately as possible were determined by preliminary tests, consisting in a series of trials conducted at a nominal output power of 300 to 400 $W$ (approximately 30 to $45 \mathrm{~kW} / \mathrm{m}^{2}$ of effective power for a $7.5 \mathrm{~mm}$ spot diameter). The results were then compared to previous observations of the effects of a real fire on the same material (Figure 2). These values were initially regarded to be more representative than the maximum fire intensity mentioned earlier $\left(100 \mathrm{~kW} / \mathrm{m}^{2}\right.$ (11)). Indeed, even the damage caused by these tests was greater than normally observed in buildings. To

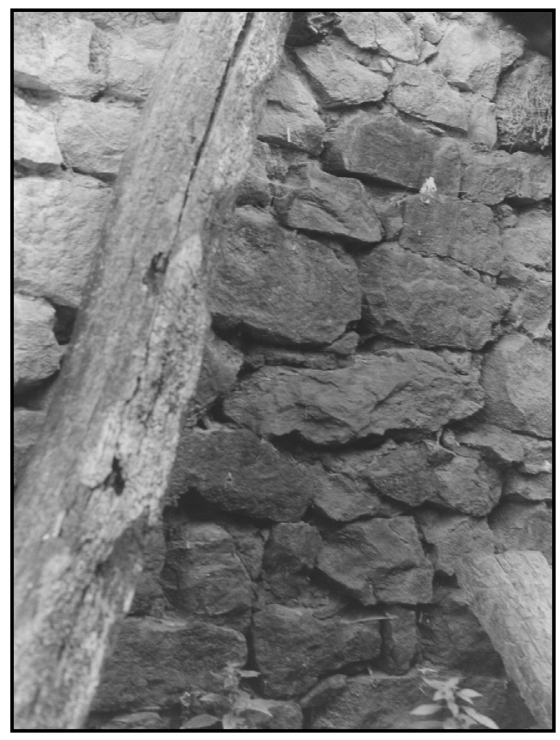

Figura 2. Fachada interior de edificio quemado construido con arenisca de Uncastillo. La zona central, más oscura, corresponde a sillares enrojecidos por acción del fuego.

Figure 2. Burnt exterior, as seen from the building interior, made with Uncastillo sandstone. The central darker area corresponds to stone blocks reddened by fire. 
grado de deterioro tras estos ensayos era muy superior a lo que se observa normalmente en los edificios. Para evitar un deterioro desproporcionado, se fue disminuyendo la potencia nominal hasta seleccionar una serie con potencias de 100,125 y $150 \mathrm{~W}\left(11,3,14,1\right.$ y $17 \mathrm{~kW} / \mathrm{m}^{2}$ efectivos para un spot de $7,5 \mathrm{~mm}$ de diámetro), con tiempos de exposición de 3 y 5 minutos para cada una de las potencias. El tamaño del spot $(7,5 \mathrm{~mm})$ se seleccionó como el menor que permitía realizar medidas de color con el aparato disponible.

El tipo de piedra seleccionado fue una arenisca conocida como Piedra de Uncastillo. Este tipo de piedra muestra cambios macroscópicos notables después de un fuego, especialmente en lo que se refiere a cambios de color, y ha sido utilizada en edificación desde tiempos romanos en la comarca de las Cinco Villas (Zaragoza, España) (19). Petrográficamente, la piedra de Uncastillo es una litoarenita calcitica granosoportada de grano medio (media 0,29 mm) con una relación esqueleto/pasta/porosidad es de 60/20/20. Los principales constituyentes del esqueleto son cuarzo (mono, policristalino y chert), fragmentos de roca carbonática, feldespato potásico, plagioclasa y moscovita. La matriz está compuesta básicamente de calcita (micrita) tanto como matriz detrítica y como pseudomatriz. La presencia de minerales de arcilla (illita fundamentalmente) es muy escasa y presenta algunos cementos esparíticos como rasgo accesorio. Esta arenisca aflora en capas lateralmente discontinuas que están relacionadas con un sistema de canales terciarios.

La arenisca se cortó en muestras de $5 \times 5 \times 2 \mathrm{~cm}$ y se realizaron cuatro exposiciones con el láser en una muestra para cada una de las condiciones seleccionadas.

Las muestras se situaron en una superficie libre y accesible sin ningún tipo de portamuestras y el cabezal del láser se situó verticalmente a la distancia requerida para obtener un spot de 7,5 mm (Figura 3). La temperatura superficial se midió con un termómetro de infrarrojos Raytek Raynger MX4 con límite máximo de lectura de $900^{\circ} \mathrm{C}$. La humedad en las zonas irradiadas y sin irradiar de las muestras se midió tras los ensayos con un Protimeter Digital Mini

Para la caracterización de los materiales antes y después del quemado se utilizaron técnicas de análisis no destructivas o que utilizaran muy poca muestra. Así, se midieron, con un espectrofotómetro Minolta CM-2002, los parámetros L* a* b* según el sistema CIELAB y el índice de blanco (WI) y amarillo (YI) según la norma ASTM-E313. Los tres parámetros CIELAB representan la luminosidad del color ( $L^{*}, L^{*}=0$ indica negro y $L^{*}=100$ blanco), su posición entre el magenta y el verde ( $a^{*}$, valores negativos indican verde y valores positivos magenta) y entre el avoid disproportionate damage, the nominal output power was lowered to 100, 125 and 150 (11.3, 14.1 and $17 \mathrm{~kW} / \mathrm{m}^{2}$ of effective power for a $7.5 \mathrm{~mm}$ spot diameter), with 3 and 5 minute exposure times. The spot size (7.5 mm) chosen was the smallest for which colour could be measured with the spectrophotometer available.

Piedra de Uncastillo was the variety of sandstone chosen. This stone, which has been used as a building material in the Cinco Villas region (Saragossa, Spain) (19) since Roman times, undergoes noticeable macroscopic change when exposed to fire, especially as far as colour is concerned. Petrographically speaking, it is a grain-supported, medium-grained (0.29 mm average) calcitic lithic arenite (calclithite) with a $60 / 20 / 20$ ratio of clasts/matrixcement/porosity. The main framework clasts are quartz (mono, polycrystalline and chert), calcitic rock fragments, $K$-feldspar, plagioclase and muscovite. The prevalent component of the matrix is calcite (micrite), forming both a detritic and a pseudo matrix with traces of clay minerals (mainly illite) and sparitic cements. This sandstone outcrops in laterally discontinuous beds that are part of a system of Tertiary channels.

The stone was cut into $5 \times 5 \times 2 \mathrm{~cm}$ specimens that were subjected to four laser irradiation trials under each of the experimental conditions.

The specimens were placed with no sample holder in an unconfined area and the laser head was oriented vertically at the appropriate distance to obtain a $7.5 \mathrm{~mm}$ spot diameter (Figure 3). The surface temperature was measured with a Raytek Raynger MX4 infrared thermometer with a range of up to $900^{\circ} \mathrm{C}$. A Protimeter Digital Mini moisture probe was used to measure the humidity in the irradiated and non-irradiated areas of the stone

The samples were characterized before and after the tests with non-destructive testing techniques wherever possible or with methods requiring very small amounts of sample material. Colour was determined with a Minolta CM-2002 spectrophotometer to the CIELAB system (parameters $L^{*}, a^{*}$ and $b^{*}$ ) as well as to standard ASTM-E313 whiteness (WI) and yellowness (YI) indices. The three CIELAB parameters describe brightness $\left(L^{*}\right.$, where $L^{*}=0$ is black and $L^{*}=100$ white), the position between magenta and green ( $a^{*}$, with negative values denoting green 


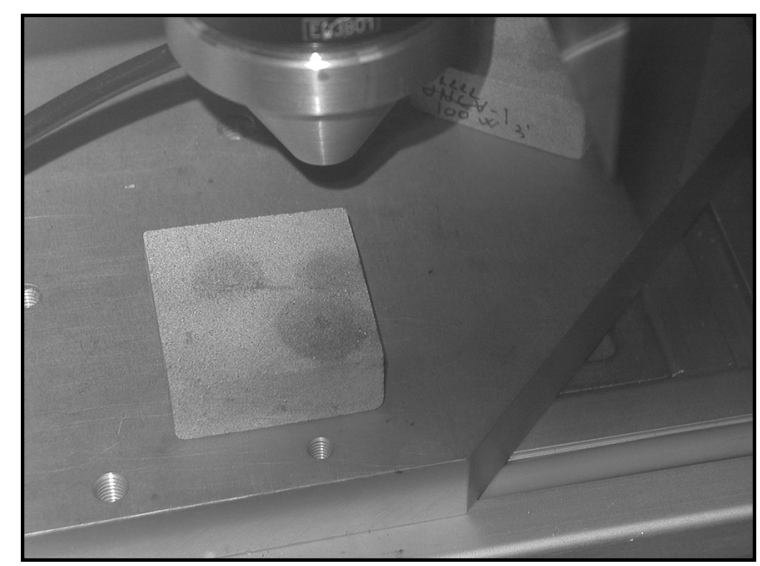

Figura 3. Área de ensayo accesible durante uno de los experimentos de calentamiento.

Figure 3. Accessible testing area during one of the heating experiments.

amarillo y el azul ( $b *$, valores negativos indican azul y valores positivos amarillo).

La rugosidad se determinó con un rugosímetro Mitutoyo SJ 201, seleccionando los parámetros Ra (media aritmética de los valores absolutos de las desviaciones desde la línea media del perfil), $R q$ (raíz cuadrada de la media aritmética al cuadrados de las desviaciones de la línea base del perfil) y $R z$ (suma de las medias de los cinco picos más altos y los cinco valles más profundos del perfil).

Las observaciones micro-texturales se realizaron con un microscopio electrónico Jeol JSM 6400 en modo de electrones secundarios SEM-SE. Para el análisis de cambios mineralógicos se utilizó un difractómetro de polvo (Philips $X^{\prime}$ pert-MPD) con portamuestras de oblea de silicio monocristal (PW1817/32) para poca cantidad de muestra (< $1 \mathrm{mg}$ ). El material para la difracción de rayos $X$ se obtuvo de las áreas irradiadas mediante un microrotor (Dremel).

\section{RESULTADOS Y DISCUSIÓN}

Como se mencionaba anteriormente, los ensayos con potencias nominales de entre 300 a $400 \mathrm{~W}$ fueron muy destructivos y sus resultados excedían lo que se observa normalmente en los edificios como resultados del fuego. Las muestras se fundieron superficialmente en apenas un minuto, indicando que se alcanzaron temperaturas superficiales superiores al punto de fusión del cuarzo $\left(1710^{\circ} \mathrm{C}\right)$ y gradientes de temperatura en la superficie de más de $1500^{\circ} \mathrm{C} / \mathrm{cm}$. A los pocos días, las muestras situadas a temperatura y humedad ambiente mostraban una fuerte disgregación de la zona afectada (Figura 4) como resultado de la rehidratación de los productos de la calcinación de la calcita.

La Figura 5 muestra la batería final de muestras irradiadas con potencias nominales entre 100 y $150 \mathrm{~W}$ y tiem- and positive values magenta) and the position between yellow and blue ( $b^{*}$, with negative values denoting blue and positive values yellow).

Roughness was determined with a Mitutoyo SJ 201 surface roughness tester and defined in terms of parameters Ra (arithmetic mean of the absolute values of the roughness profile ordinates), $R q$ (root mean square average of the roughness profile ordinates) and $R z$ (sum of the vertical distance between the five highest peaks and the five deepest valleys within the sampling length).

Micro-textural observations were made with a Jeol JSM 6400 electron microscope using secondary electron imaging (SEM-SE). Mineralogical changes were detected with a Philips X'pert-MPD powder diffractometer fitted with a single crystal silicon sample holder (PW1817/32) designed for mounting very small amounts of powder $(<1 \mathrm{mg})$. The $X$-ray diffraction (XRD) samples were prepared by grinding the irradiated areas with a high speed rotary tool (Dremel).

\section{RESULTS AND DISCUSSION}

As noted in the preceding section, the tests conducted at a nominal output power of 300 to $400 \mathrm{~W}$ proved to be much more destructive than which is normally observed after building fires. The sample surfaces melted after only one minute, an indication of temperatures higher than the melting point of quartz $\left(1710^{\circ} \mathrm{C}\right)$ and surface temperature gradients in excess of $1500^{\circ} \mathrm{C} / \mathrm{cm}$. After a few days at room temperature and ambient humidity, the burnt areas showed severe granular disaggregation (Figure 4) as a result of the hydration of calcination products.

Figure 5 shows the series of specimens irradiated at nominal output powers of 100 to $150 \mathrm{~W}$ for 3 and 5 minu- 


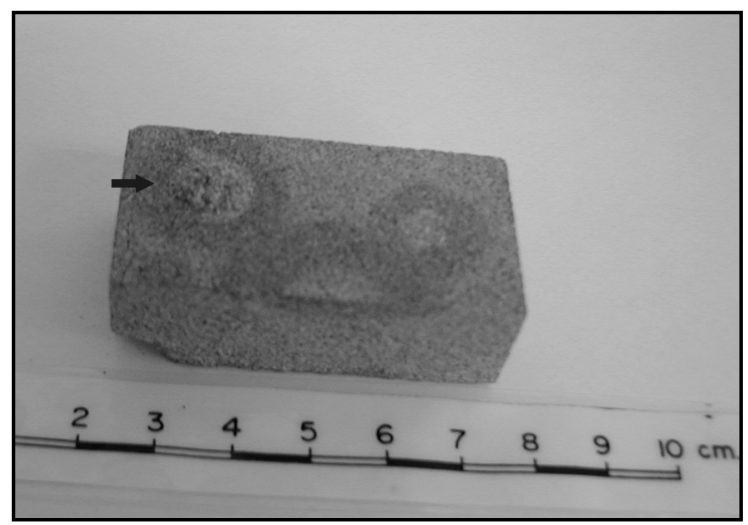

Figura 4. Material suelto por disgregación granular de uno de los puntos calentados con potencias nominales de $300 \mathrm{~W}$.

Figure 4. Loose material through granular disaggregation of one of the spots heated with $300 \mathrm{~W}$ rated power.

pos de exposición desde el comienzo de la estabilización de la temperatura de 3 y 5 minutos. Estos ensayos se consideraron como los más representativos del rango de deterioro observado en edificios quemados.

La evolución de la temperatura superficial durante los ensayos sigue la función general representada en la Figura 6. La temperatura superficial aumenta logarítmicamente. Cuando la pendiente de la función de temperatura desciende hasta acercarse a cero, indica que el material ha llegado a un estado de equilibrio, en el que la energía que recibe es igual a la que puede absorber. La Tabla 1 muestra los tes from surface temperature stabilization. These tests were regarded to be the most representative of the decay observed in buildings exposed to fire.

The variation in surface temperature during the test adopts the general pattern shown in Figure 6. Surface temperature increases logarithmically, then slope decreases to a value near zero, indicating that the material has reached an equilibrium state in which the absorbed energy equals the maximum the material could absorb. Table 1 shows the surface temperatures at stabilization

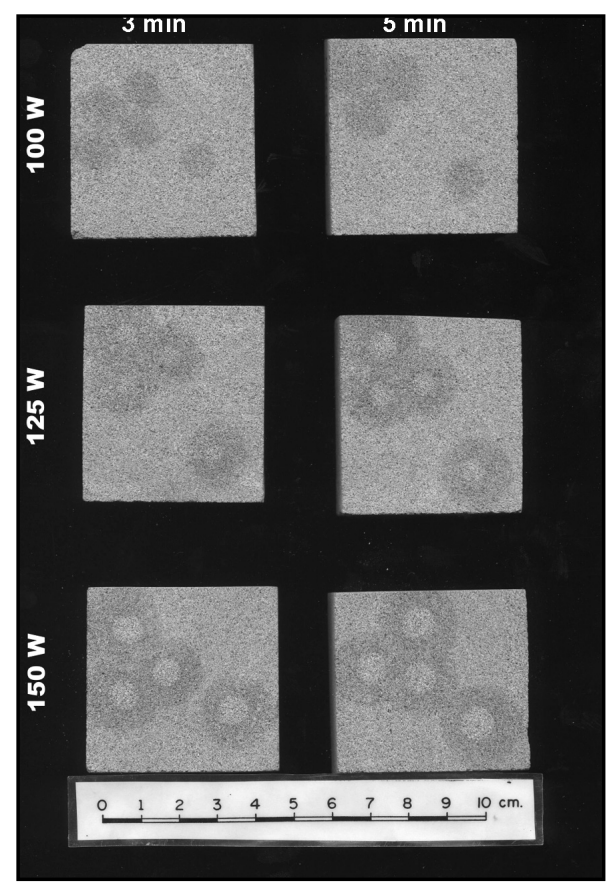

Figura 5. Batería completa de muestras calentadas con diferentes potencias y tiempos.

Figure 5. Complete set of samples heated at different power and time. 


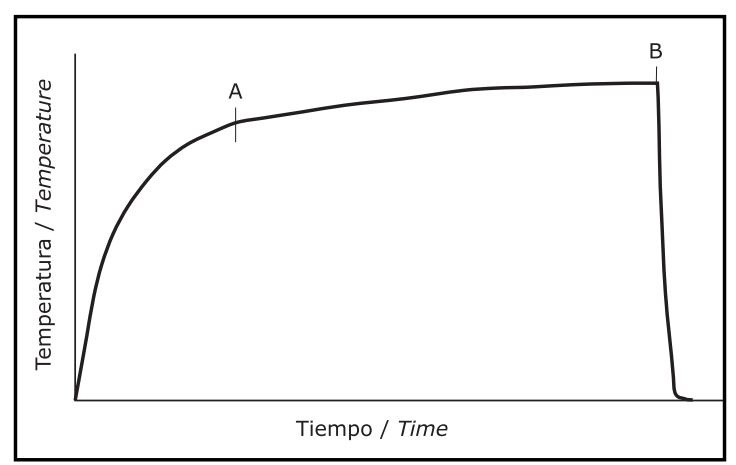

Figura 6. Caso general de evolución de la temperatura superficial durante el calentamiento con el láser. La temperatura aumenta inicialmente de forma logarítmica hasta el equilibrio parcial (A), para luego evolucionar con una pendiente cercana a la horizontal hasta el final del ensayo de calentamiento (B).

Figure 6. General case of surface temperature evolution during laser heating. Initially, temperature increases logarithmically until a partial equilibrium $(A)$, to after evolve with a slope near zero until the end of the heating test (B).

valores de temperatura de superficie obtenidos en cada uno de los ensayos en el momento de la estabilización de la temperatura (marcado como A en la Figura 6) y al final de los 3 ó 5 minutos de ensayo (marcado como B en la Figura 6). Los valores de la temperatura final y máxima dependen de las propiedades térmicas del material (calor específico, conductividad térmica) y de los cambios quími$\cos y /$ estructurales que se producen en el material durante el calentamiento, ya que la energía térmica recibida durante el calentamiento se invierte en estos cambios. Los datos de la Tabla 1 para los ensayos a $150 \mathrm{~W}$ muestran, por ejemplo, el efecto que tiene sobre la evolución de la temperatura la reacción endotérmica de calcinación de la calcita. La energía invertida en este proceso se traduce en una temperatura final en el ensayo de calentamiento tras 5 minutos inferior que en el ensayo de 3 minutos. (point $A$ on Figure 6) and after 3 or 5 minutes at the end of the test (point $B$ on Figure 6). The end and peak temperatures depended on the thermal properties of the stone (specific heat, thermal conductivity) as well as the chemical and structural changes induced in the material by the thermal energy received. For example, the results at $150 \mathrm{~W}$ given in Table 1 show the effects of the endothermic calcite calcination reaction. The energy spent in this process results in a final surface temperature in the 5 minute test which is lower than in the 3 minute test.

Tabla 1 / Table 1

Temperaturas superficiales medidas al comienzo de la estabilización de los valores $\left({ }^{\circ} \mathrm{C}\right)(\mathrm{A})$ y al final del experimento (B) para cada uno de los ensayos. A y B se relacionan con los puntos representados en la Figura 6.

Surface temperatures measured at the beginning of the stabilization $\left({ }^{\circ} \mathrm{C}\right)(\mathrm{A})$ and at the end of the experiment $(B)$ for each of the tests. $A$ and $B$ refer to the points represented in Figure 6.

\begin{tabular}{|c|c|c|c|c|c|c|}
\hline & \multicolumn{2}{|c|}{$100 \mathrm{~W}\left(11,3 \mathrm{~kW} / \mathrm{m}^{2}\right)$} & \multicolumn{2}{|c|}{$125 \mathrm{~W}\left(14,1 \mathrm{~kW} / \mathrm{m}^{2}\right)$} & \multicolumn{2}{|c|}{$150 \mathrm{~W}\left(16,9 \mathrm{~kW} / \mathrm{m}^{2}\right)$} \\
\hline & $3 \mathrm{~min}$ & $5 \mathrm{~min}$ & $3 \mathrm{~min}$ & $5 \mathrm{~min}$ & $3 \mathrm{~min}$ & $5 \mathrm{~min}$ \\
\hline $\mathbf{A}$ & $330^{\circ}$ & $330^{\circ}$ & $450^{\circ}$ & $450^{\circ}$ & $600^{\circ}$ & $600^{\circ}$ \\
\hline B & $400^{\circ}$ & $430^{\circ}$ & $620^{\circ}$ & $780^{\circ}$ & $800^{\circ}$ & $750^{\circ}$ \\
\hline
\end{tabular}

Con respecto al color, existe una evolución clara del color con respecto a la temperatura. La Tabla 2 recoge las medidas de color en los diferentes ensayos mientras que los gráficos de la Figura 7 muestran los valores de $L^{*}$ y a* con respecto a la temperatura final alcanzada en los ensayos. Los parámetros $L^{*}$ y $a^{*}$ son los que muestran más claramente la evolución del color con la temperatura. $L^{*}$ desciende inicialmente a $300{ }^{\circ} \mathrm{C}$ para aumentar
Colour, in turn, clearly changed with temperature. Table 2 gives the post-test colour measurements, while the graphs in Figure 7 plot the $L^{*}$ and $a^{*}$ values versus the final temperature, for these were the two parameters that reflected colour variations most clearly. L* initially declined with temperature up to $300{ }^{\circ} \mathrm{C}$ and subsequently rose, whereas parameter a* (green-magenta axis in the CIELAB system) behaved conversely, rising up to 
Tabla 2 / Table 2

Medidas de color en muestras de arenisca de Uncastillo (valores medios y desviación estándar a partir de 10 medidas para las muestras sin irradiar y 5 medidas para cada uno de los ensayos).

Colour measures for Uncastillo sandstone (average and standard deviation from 10 measures in the fresh samples and 5 measures in each of the tests).

\begin{tabular}{|c|c|c|c|c|c|}
\hline \multicolumn{7}{|c|}{ 3 minutos / minutes } \\
\hline & L* & a* & b* & WI & YI \\
\hline Sin irradiar / fresh & $64.4 \pm 0.6$ & $2.6 \pm 0.1$ & $13.9 \pm 0.6$ & $-4.0 \pm 1.0$ & $28.0 \pm 1.0$ \\
\hline $100 \mathrm{~W}\left(11.3 \mathrm{~kW} / \mathrm{m}^{2}\right)$ & $58.8 \pm 0.9$ & $7.3 \pm 0.3$ & $12.9 \pm 0.6$ & $-3.0 \pm 1.0$ & $28.0 \pm 1.0$ \\
\hline $125 \mathrm{~W}\left(14.1 \mathrm{~kW} / \mathrm{m}^{2}\right)$ & $59.0 \pm 0.7$ & $6.7 \pm 0.5$ & $12.3 \pm 0.4$ & $-2.0 \pm 1.0$ & $26.8 \pm 0.9$ \\
\hline $150 \mathrm{~W}\left(16.9 \mathrm{~kW} / \mathrm{m}^{2}\right)$ & $62.8 \pm 0.7$ & $5.5 \pm 0.3$ & $11.4 \pm 0.6$ & $1.0 \pm 1.0$ & $24.0 \pm 1.0$ \\
\hline \multicolumn{7}{|c|}{$\mathbf{5}$ minutos / minutes } & WI & YI \\
\hline \multicolumn{7}{|c|}{$\mathbf{5}$} & $\mathbf{a *}$ & $\mathbf{b *}$ & $28.0 \pm 1.0$ \\
\hline Sin irradiar / fresh & $64.4 \pm 0.6$ & $2.6 \pm 0.1$ & $13.9 \pm 0.6$ & $-4.0 \pm 1.0$ & $29.0 \pm 1.0$ \\
\hline $100 \mathrm{~W}\left(11.3 \mathrm{~kW} / \mathrm{m}^{2}\right)$ & $60.0 \pm 2.0$ & $7.0 \pm 1.0$ & $13.4 \pm 0.8$ & $-4.0 \pm 2.0$ & $25.0 \pm 2.0$ \\
\hline $125 \mathrm{~W}\left(14.1 \mathrm{~kW} / \mathrm{m}^{2}\right)$ & $60.0 \pm 2.0$ & $5.9 \pm 0.4$ & $11.5 \pm 0.9$ & $0.0 \pm 2.0$ & $25.5 \pm 0.9$ \\
\hline $150 \mathrm{~W}\left(16.9 \mathrm{~kW} / \mathrm{m}^{2}\right)$ & $62.0 \pm 1.0$ & $5.7 \pm 0.4$ & $12.2 \pm 0.4$ & $-1.0 \pm 1.0$ &
\end{tabular}
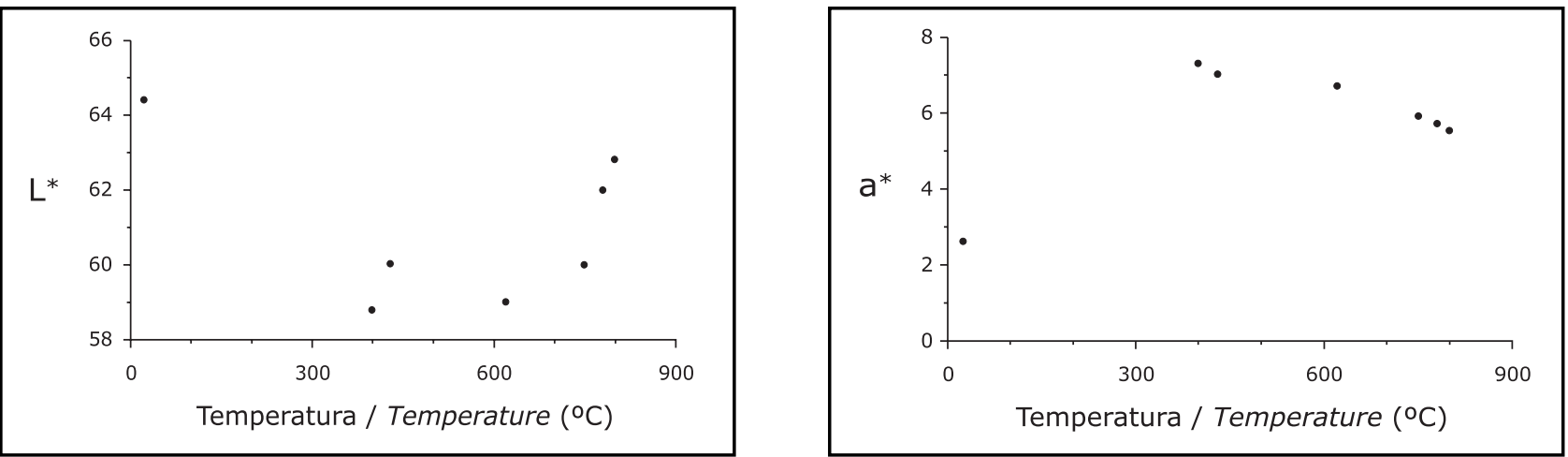

Figura 7. Variación de los parámetros cromáticos $L^{*}$ y a* en función de la temperatura final (B en la Tabla 1) para cada uno de los ensayos.

Figure 7. Variation of colour parameters $L^{*}$ and $a^{*}$ in relation to the final temperature ( $B$ in Table 1 ) for each of the tests.

progresivamente a medida que aumenta la temperatura de calentamiento. De manera inversa, el parámetro a* (eje verde-magenta en el sistema CIELAB) aumenta inicialmente a $300^{\circ} \mathrm{C}$ y después disminuye progresivamente a medida que aumenta la temperatura. El primero de estos cambios se debe al enrojecimiento del material causado por la termo-oxidación del hierro. A partir de ahí, a medida que aumenta la temperatura, el color de las zonas afectadas cambia hacia colores más blanquecinos, debido a la evolución del proceso de calcinación. Estas tendencias se reflejan también en el resto de los parámetros cromáticos.

Las zonas blanquecinas observables en los ensayos a mayores temperaturas adquieren un relieve positivo pasadas unas 24 horas desde los ensayos. Estas zonas blanquecinas absorben más humedad $(9,4 \%)$ que la zona
$300{ }^{\circ} \mathrm{C}$ and declining at higher temperatures. The first change was the result of the stone reddening occasioned by iron thermal oxidation. After $300^{\circ} \mathrm{C}$, the colour in the areas affected turned whiter as a result of calcination, aprocess likewise reflected in the values of the other chromatic parameters.

The whitened areas, visible in the specimens subjected to higher temperatures, began to protrude 24 hours after the tests and were observed to absorb more humidity 
circundante rojiza (8,8\%). Tanto el aumento de volumen y de grado de humedad se debe a la hidratación de los productos de la calcinación.

Con respecto a la rugosidad de las muestras (Tabla 3), se observa un descenso inicial seguido de un aumento progresivo de la rugosidad superficial. La Figura 8 muestra como ejemplo la evolución del parámetro Rz con la temperatura final. Este parámetro se ha seleccionado para la gráfica por ser el que presenta menor dispersión de los resultados. La Figura 9 recoge el perfil topográfico de una de las muestras tras el calentamiento. La zona irradiada adquiere un relieve positivo con respecto al resto de la muestra y aumenta su rugosidad, especialmente en la zona central, lo que otorga al perfil una morfología de tipo atolón.
(9.4\%) than the surrounding reddish zones (8.8\%) Both changes were the result of calcination product hydration.

Although surface roughness initially declined in the specimens (Table 3), after $300{ }^{\circ} \mathrm{C}$ it was observed to rise with temperature. By way of example, Figure 8 shows how the variation in the final temperature affected $R z$, of the three roughness parameters the one with the least scattered results. Figure 9 shows the topography of one of the samples after heating. The area irradiated protruded outward, with surface roughness increasing more prominently in the middle of the spot to form a profile with an atoll type morphology.

Tabla 3 / Table 3

Parámetros de rugosidad superficial en muestras de arenisca de Uncastillo (valores medios y desviación estándar a partir de 10 medidas para la muestra sin irradiar y 3 medidas para cada una de los ensayos).

Surface roughness parameters for Uncastillo sandstone (average and standard deviation from 10 measures in the fresh samples and 3 measures in each of the tests).

\begin{tabular}{|c|c|c|c|}
\hline \multicolumn{5}{|c|}{ 3 minutos / minutes } \\
\hline & Ra ( $\boldsymbol{\mu m})$ & $\mathbf{R q}(\boldsymbol{\mu m})$ & $\mathbf{R z}(\boldsymbol{\mu m})$ \\
\hline Sin irradiar / fresh & $17 \pm 2$ & $21 \pm 2$ & $66 \pm 6$ \\
\hline $100 \mathrm{~W}\left(11,3 \mathrm{~kW} / \mathrm{m}^{2}\right)$ & $22 \pm 2$ & $27 \pm 2$ & $81 \pm 6$ \\
\hline $125 \mathrm{~W}\left(14,1 \mathrm{~kW} / \mathrm{m}^{2}\right)$ & $19 \pm 3$ & $23 \pm 3$ & $62 \pm 1$ \\
\hline $150 \mathrm{~W}\left(16,9 \mathrm{~kW} / \mathrm{m}^{2}\right)$ & $19 \pm 2$ & $24 \pm 2$ & $72 \pm 6$ \\
\hline \multicolumn{5}{|c|}{$\mathbf{5}$ minutos / minutes } & $\mathbf{R z}(\boldsymbol{\mu m})$ \\
\hline \multicolumn{5}{|c|}{$\mathbf{R a}(\boldsymbol{\mu m})$} & $21 \pm 2$ & $66 \pm 6$ \\
\hline Sin irradiar / fresh & $17 \pm 2$ & $20 \pm 2$ & $77 \pm 7$ \\
\hline $100 \mathrm{~W}\left(11,3 \mathrm{~kW} / \mathrm{m}^{2}\right)$ & $16 \pm 1$ & $24 \pm 2$ & $72 \pm 9$ \\
\hline $125 \mathrm{~W}\left(14,1 \mathrm{~kW} / \mathrm{m}^{2}\right)$ & $18 \pm 1$ & $24 \pm 3$ & \\
\hline $150 \mathrm{~W}\left(16,9 \mathrm{~kW} / \mathrm{m}^{2}\right)$ & $18 \pm 2$ &
\end{tabular}

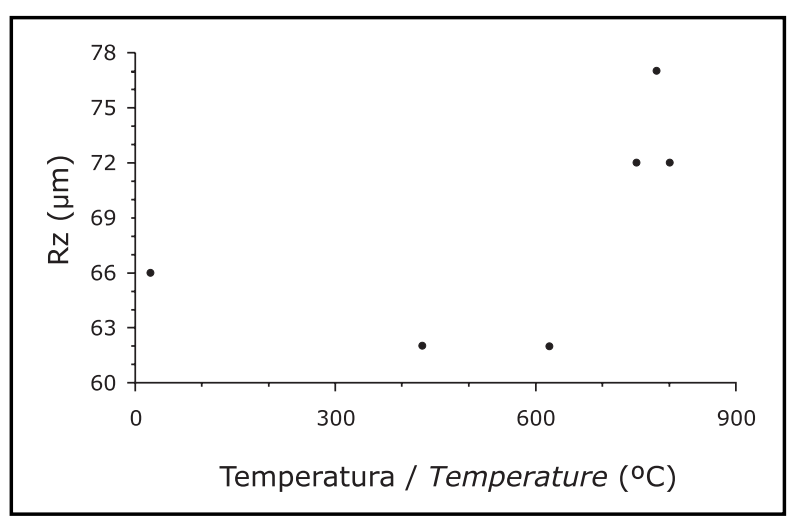

Figura 8. Variación del parámetro de rugosidad superficial Rz en función de la temperatura final ( $B$ en la tabla 1) para cada uno de los ensayos.

Figure 8. Variation of surface roughness parameter $R z$ in relation to the final temperature ( $B$ in table 1) for each of the tests. 


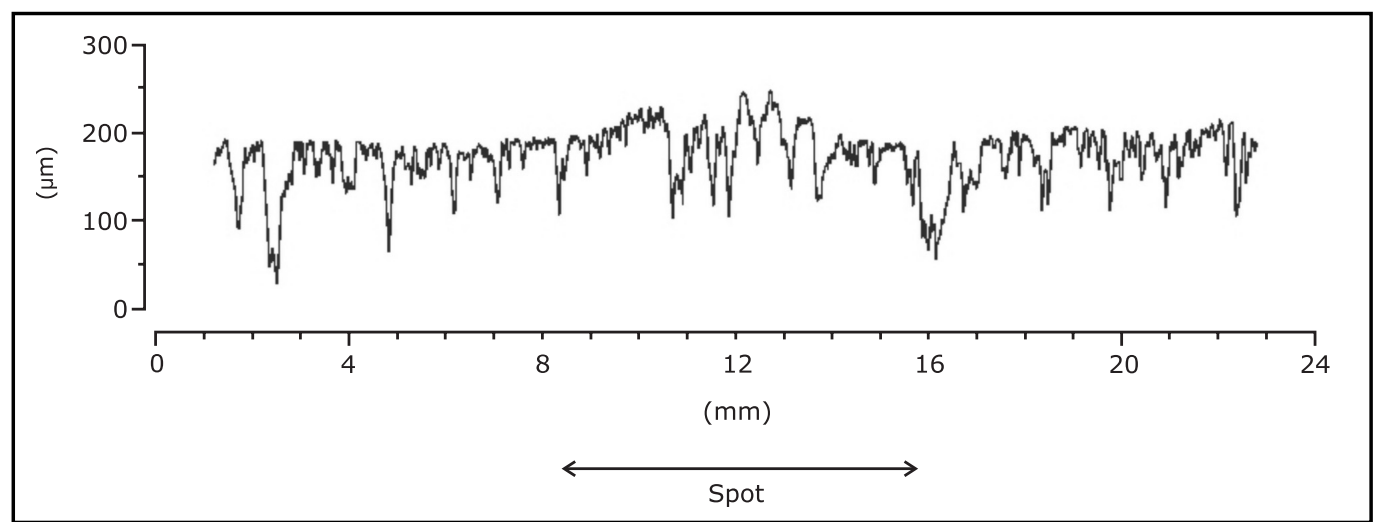

Figura 9. Perfil de la superficie de una muestra en la zona irradiada con el láser durante 5 minutos a $150 \mathrm{~W}$.

Figure 9. Surface profile of a sample in the area irradiated with the laser during 5 minutes at $150 \mathrm{~W}$.

El cambio mineralógico más notable tras el calentamiento es la calcinación de la calcita. En las muestras calentada a $800{ }^{\circ} \mathrm{C}$, la proporción relativa de calcita disminuye notablemente y aparecen en los difractogramas pequeños picos de óxido de calcio y portlandita $\mathrm{Ca}(\mathrm{OH})^{2}$, debido a la reacción del óxido de calcio con la humedad ambiental. La reacción del óxido de calcio para formar portlandita supone un aumento de volumen de un $20 \%$ (6) y es la principal causa del aumento de relieve y grado de humedad que se observa en las muestras calentadas a mayores temperaturas tras su exposición a la humedad ambiental.

Las observaciones de microscopía electrónica ilustran este proceso de calcinación. La figura 10 corresponde a una muestra sin irradiar en la que se observan los granos minerales embutidos en una abundante matriz calcárea (a) e irradiada hasta $780{ }^{\circ} \mathrm{C}$, en la que se observa cómo se han perdido fragmentos de la matriz calcárea y un aumento de la fisuración y rugosidad superficial en algunos cristales (b). La illita también muestra cambios con la temperatura, abriéndose su estructura laminar.

Los resultados de los ensayos realizados con láser muestran una buena correlación de con los obtenidos en otros
The most conspicuous heat-induced mineralogical change was calcite calcination. In the specimens heated to $800{ }^{\circ} \mathrm{C}$, the proportion of calcite declined substantially, while small peaks attributed to calcium oxide and portlandite $\mathrm{Ca}(\mathrm{OH})_{2}$, the product of the reaction between calcium oxide and the ambient humidity, appeared on the $X R D$ patterns. The protrusions and the increase in moisture observed in specimens heated to higher temperatures were primarily a result of the hydration of calcium oxide with the ambient humidity to form portlandite, with a concomitant $20 \%$ increase in volume (6).

This calcination process was observable under the electron microscope. Prior to irradiation (a), the specimen in Figure 10 had grains imbedded in an abundant calcareous matrix. After irradiation to a temperature of $780^{\circ} \mathrm{C}$ (b) whole fragments of the matrix fell away and cracking and roughness were observed to increase in some crystals. The rise in temperature also affected illite, widening the space between its structural laminae.

The above laser test results are consistent with findings from other previously reported furnace tests of sandsto-

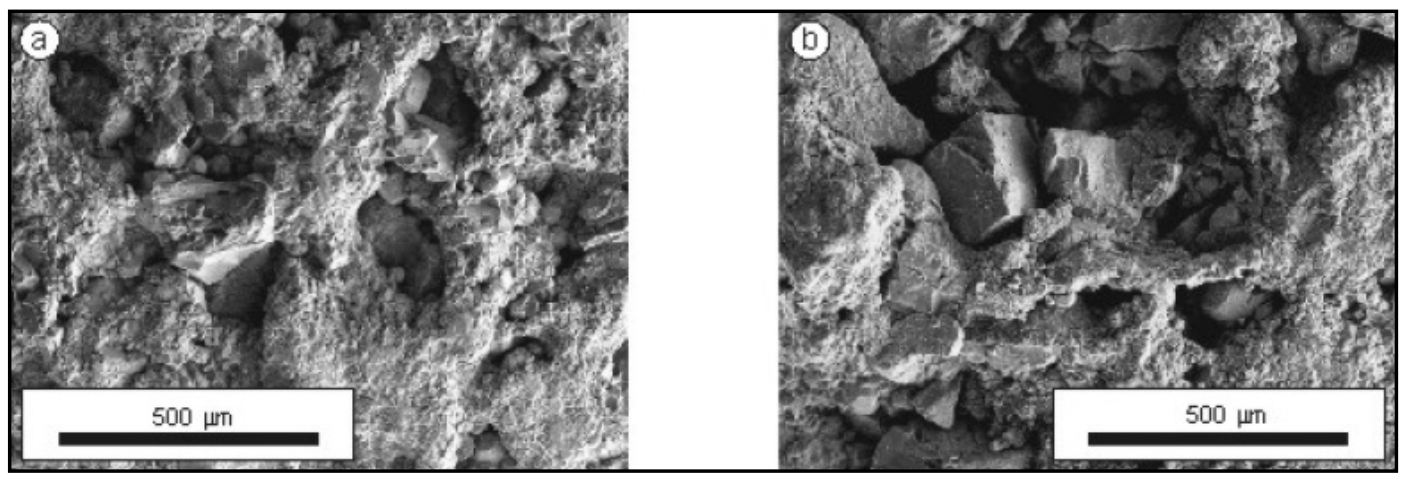

Figura 10. Imágenes SEM-SE de la Piedra de Uncastillo sin calentar (a) y calentada a $780^{\circ} \mathrm{C}$ (b). Figure 10. SEM-SE images of fresh Piedra de Uncastillo (a) and after heating at $780{ }^{\circ} \mathrm{C}$ (b). 
experimentos en areniscas y calizas ensayadas con hornos (4-7). En todos los casos se observa una evolución cromática y mineralógica similar con el aumento de temperatura, observándose el enrojecimiento debido a la termo-oxidación del hierro a 250-300 ${ }^{\circ} \mathrm{C}$, cambios en la estructura de la illita a partir de $550{ }^{\circ} \mathrm{C}$ y calcinación de la calcita desde $800{ }^{\circ} \mathrm{C}$ como cambios principales. De igual forma, las observaciones microscópicas tras los ensayos realizados con el láser muestran una microestructura similar a la de las muestras quemadas en incendios reales de edificios construidos con este mismo tipo de piedra $(14,15)$. De igual forma, los resultados obtenidos con irradiación láser muestran los mismos procesos y pautas de fisuración de minerales, aumento de la rugosidad superficial de los cristales, modificación textural de los minerales arcillosos y pérdida de matriz calcítica que se observan tras fuegos reales en edificios y otros métodos de ensayo.

Sin embargo, los resultados obtenido con láser, se han logrado utilizando una cantidad de muestra significativamente menor, ya que el volumen total de piedra irradiada en cada ensayo corresponde a un casquete esférico de aproximadamente $0,176 \mathrm{~cm}^{3}$.

\section{CONCLUSIONES}

Los ensayos sobre la aplicabilidad del uso de la irradiación láser para estudiar los cambios que el calentamiento durante un fuego produce en la piedra son muy positivos. Los resultados obtenidos son consistentes con lo observado en edificios de piedra quemados y en otros tipos de ensayo de calentamiento de materiales pétreos, pero con la ventaja de la poca muestra que se necesita para los ensayos.

Aunque esta técnica no resultaría adecuada para estudios de propiedades de conjunto, los resultados mostrados animan a considerar el láser como una técnica mínimamente invasiva adecuada para el estudio de los cambios a pequeña escala que sufre la piedra calentada durante un incendio. Esto es especialmente útil si se ha de considerar el uso de muestras provenientes de edificios con valor patrimonial. El uso de este tipo de muestras es recomendable para evaluar correctamente el alcance del deterioro, puesto que los materiales situados en un edificio han sufrido una historia de agentes de deterioro muy diferente a la de un material de cantera. Más aún, el alto grado de control que se obtiene sobre los parámetros experimentales garantiza una alta repetibilidad de los ensayos. También, el calentamiento mediante irradiación láser simula mejor el régimen de calentamiento que se produce en un incendio que el calentamiento por convección propio de los hornos. ne and limestone (4-7). The chromatic and mineralogical variations with temperature were observed to be similar in all cases, with thermal oxidation-induced reddening between 250 and $300{ }^{\circ} \mathrm{C}$, changes in illite structure after $550{ }^{\circ} \mathrm{C}$ and calcite calcination at temperatures from $800{ }^{\circ} \mathrm{C}$. Moreover, SEM observations showed that the micro-texture was similar in laser-tested specimens and samples of the same type of stone burnt in real fires (14, 15). At the same time, the mineral cracking, increased crystal surface roughness, clay mineral textural changes and loss of calcitic matrix observed in laser heated specimens revealed processes and patterns similar to those observed after real building fires and on samples tested with other methods.

Lastly, significantly smaller samples could be used in laser testing, as the total volume of irradiated stone in each test corresponds to a spherical cap of approximately $0.176 \mathrm{~cm}^{3}$.

\section{CONCLUSIONS}

The tests to ascertain the suitability of laser irradiation for studying fire-induced changes in stone yielded very promising results. The findings were consistent with observations of the effects on stone of real fire and other experimental treatments, but with the added advantage of the small amount of sample required.

While laser is inappropriate for studying bulk properties, the results of this research indicate that it is a minimally invasive technique that can be used to explore the microscale changes taking place in stone after a fire. It is particularly useful when sampling heritage buildings, where it is recommended for the accurate assessment of the scope of decay, for materials in buildings are subject to different deterioration mechanisms than quarry stone. In addition, test repeatability is ensured because the experimental parameters can be strictly controlled. Furthermore, the heat generated by laser irradiation simulates the pattern found in fires more closely than the convection heating characteristic of furnaces. 
La posibilidad de realizar ensayos abiertos supone otra ventaja; pues se puede interaccionar con la muestra durante los ensayos, lo que potencialmente permite incluir otros factores adicionales al cambio de temperatura que están asociados con el fuego, como es la presencia de cenizas u otros residuos de la combustión.

Las futuras investigaciones sobre esta técnica se deben dirigir hacia la implementación de su uso para realizar ensayos in situ sobre los edificios, dado que esta técnica no requiere el uso de ningún tipo de portamuestras.

\section{AGRADECIMIENTOS}

Esta investigación ha sido posible a través de la colaboración de grupos dentro del proyecto MATERNAS_CM 0505/MAT/0094. Los autores quieren agradecer a los revisores así como a $\mathrm{K}$. Dotter por sus comentarios al manuscrito
Another advantage is that in laser heating the specimens can be tested in unconfined spaces, allowing for interaction with the sample during the test and, potentially, the analysis of other fire-related factors such as ashes and combustion residue.

Future research with laser irradiation should be geared to on-site building tests, inasmuch as the technique calls for no sample holders.

\section{ACKNOWLEDGEMENTS}

This research was conducted jointly by teams participating in project MATERNAS_CM 0505/MAT/0094. The authors wish to thank the reviewers and $K$. Dotter for their comments on the manuscript.

\section{BIBLIOGRAFÍA / BIBLIOGRAPHY}

(1) Goudie, A. S., Allison, R. J. \& McLaren, S. J.: "The relations between modulus of elasticity and temperature in the context of the experimental simulation of rock weathering by fire", Earth Surf. Proc. Land., 17 (1992), pp. 605-615.

(2) Allison, R. J. \& Goudie, A. S.: "The effects of fire on rock weathering: An experimental study", in: D.A. Robinson y R.B.G. Williams (eds.), Rock Weathering and Landform Evolution. Wiley, Chichester, (1994), pp. 41-56.

(3) Chakrabarti, B., Yates, T. \& Lewry, A.: "Effect of fire damage on natural stonework in buildings". Constr. Build. Mater., 10(7) (1996), pp. 539-544.

(4) Hajpál, M.: "Changes in Sandstones of Historical Monuments Exposed to Fire or High Temperature", Fire Technol., 38(4) (2002), pp. 373-382.

(5) Hajpál, M.: "Effect of Fire Damage of Sandstones in Laboratory Conditions", in: L. Aires-Barros, F. Zezza, A. Dionisio \& M. Rodrigues (eds.), Influence of the Environment and Defense of the Territory on Recovery of Cultural Heritage. Lectures and Proceedings of the 6th International Symposium on the Conservation of Monuments in the Mediterranean Basin, Lisboa, (2004), pp. $267-272$.

(6) Hajpál, M. \& Török, A.: "Mineralogical and colour changes of quartz sandstones by heat", Environ. Geol., 46 (2004), pp. $311-322$.

(7) Gomez-Heras, M., Hajpál, M., Álvarez de Buergo, M., Török, A., Fort, R., \& Varas, M. J.: "Evolution of porosity in Hungarian building stones after simulated burning". in: R. Fort, M. Álvarez de Buergo, M. Gomez-Heras \& C. Vazquez-Calvo (eds.), Heritage Weathering and Conservation HWC-2006. Taylor \& Francis, Rotterdam (2006), pp. 513-519.

(8) McCabe, S., Smith, B. J. \& Warke, P. A.: "Preliminary observations on the impact of complex stress histories on the response of sandstone to salt weathering: laboratory simulations of process combinations", Environ. Geol., 52 (2007), pp. 251-258.

(9) McCabe, S., Smith, B. J. \& Warke, P. A.: "A legacy of mistreatment: understanding the decay of medieval sandstones in NE Ireland", Build. Environ., In press.

(10) McCabe, S., Smith, B. J. \& Warke, P. A.: "Sandstone response to salt weathering following simulated fire damage: a comparison of the effects of furnace heating and fire". Earth Surf. Proc. Land., 32 (2007), pp. 1874-1873.

(11) Ollier, C. D. \& Ash, J. E.: "Fire and rock breakdown". Zeitschr. Geomorphologie N. F., 27(3) (1983), pp. 363-374.

(12) Yuen, W. W. \& Chow, W. K.: "The role of thermal radiation on the initiation of flashover in a compartment fire". Int. J. Heat Mass Tran., 47(19-20) (2004), pp. 4265-4276.

(13) Yuen, W. W. \& Tien, C. L.: "A simplified calculation scheme for the luminous flame emissivity", In: Proceeding of the 16th Symposium (International) of Combustion, Combustion Institute, Pittsburgh (1976), pp. 1481-1487

(14) Gómez-Heras, M., Varas, M. J., Alvarez de Buergo, M. \& Fort, R.: "Characterization of changes in matrix of sandstones affected by historical fires" in: D. Kwiatkowski \& R. Löfvendahl (eds.), 10th International Congress on Deterioration and Conservation of Stone, Stockholm (2004), pp. 561-568.

(15) Gómez-Heras, M.: "Procesos y formas de deterioro térmico en piedra natural del patrimonio arquitectónico". Madrid: UCM, Servicio de Publicaciones, (2006). http://www.ucm.es/BUCM/tesis/geo/ucm-t28551.pdf Last access 15/10/07

(16) Warke, P. A. \& Smith, B. J.: "Effects of direct and indirect heating on the validity of rock weathering simulation studies and durability tests". Geomorphology, 22(3-4) (1998), pp. 347-357.

(17) Gómez-Heras M., Smith, BJ, \& Fort, R: "Surface temperature differences between minerals in crystalline rocks: implications for granular disaggregation of granites through thermal fatigue". Geomorphology 78(3-4) (2006), pp. 236-249. 
(18) Gomez-Heras, M., Álvarez de Buergo, M., Varas, M. J., Fort, R., Morcillo, M. \& Molpeceres, C.: "Fire damage of heritage building stones: methodological considerations on current research", in: G. Mileva \& M. Hristova (eds.), Built Heritage: Fire Loss to Historic Buildings, SKALA, Varna (2006), pp. 132-141.

(19) Buj, O. \& Gisbert, J.: "Petrophysical characterization of three commercial varieties of Miocene sandstones from the Ebro valley", Mater. Construcc. vol. 57, no 287 (2007), pp. 63-74. 